\title{
THE INTERNET: EQUALIZER OF FREEDOM OF SPEECH? A DISCUSSION ON FREEDOM OF SPEECH ON THE INTERNET IN THE UNITED STATES AND INDIA
}

\author{
Farzad Damania*
}

\section{INTRODUCTION}

International law states that everyone has the right to freedom of opinion and expression. ${ }^{1}$ These rights help underpin democracy and public participation. $^{2}$ New technologies, such as the Internet, provide an unprecedented opportunity to promote freedom of speech globally. Regrettably, some democratic governments are busy enacting regulations that inhibit the Internet's power. ${ }^{3}$ This paper discusses freedom of speech ${ }^{4}$ on the Internet within two of the world's largest democracies, the United States and India. $^{5}$

In the United States and India, similar constitutional provisions have yielded completely different standards for the protection of speech in

* LL.B., LL.M. The author is an attorney from Bombay, India and is presently a legal consultant with the Law offices of Jonathan Clark Green P.C. in Chicago. He is also a Research Associate in the Dean's Office of Chicago-Kent College of Law. The views expressed herein are those of the author and do not necessarily express those of the firm or the college. Thanks are due to Professor Sarah Harding, Wonah Kim, Francisco Perez Ferriera and the editors of IICLR for their valuable insight.

1. See International Covenant on Civil and Political Rights, opened for signature Oct. 5, 1977, art. 19(2), 999 U.N.T.S. 171,179 (entered into force Mar. 23, 1976), which states, "Everyone shall have the right to freedom of expression; this right shall include freedom to seek, receive and impart information and ideas of all kinds, regardless of frontiers, either orally, in writing or in print, in the form of art, or through any other media of his choice;" See also, Universal Declaration of Human Rights, art. 19, G.A. Res. 217A (III), U.N. GAOR, 3d Sess., U.N. Doc. A/810 (1948), which states, "Everyone has the right to freedom of opinion and expression; this right includes freedom to hold opinions without interference and to seek, receive and impart information and ideas through any media and regardless of frontiers."

2. See Article 19: The Global Campaign for Free Expression, available at http://www.article19.org/homepage.asp (last visited Jan. 28, 2002).

3. See Human Rights Watch, Freedom of Expression on the Internet, available at http://www.hrw.org/wr2k/issues-04.htm (last visited Feb. 4, 2002).

4. "Speech," as used in this article, includes words, pictures, sculptures, non-verbal symbols, etc. This article focuses on freedom of speech as applied to obscene speech.

5. H.R. 572, 106th Cong., 2d Sess. This Resolution, titled Indian Prime Minister's Visit to the United States, states:

Whereas the United States and the Republic of India are two of the world's largest democracies that together represent one-fifth of the world's population and more than one-fourth of the world's economy; Whereas the United States and Indian share common ideals and a vision for the 21 st century, where freedom and democracy are the strongest foundations for peace and prosperity; 
conventional media. ${ }^{6}$ Recent legislation by the United States and India reflect the emergence of new standards for the regulation of Internet speech. These new standards aim at preserving distinctions that have evolved in conventional media. Because of the very nature of the Internet, however, these distinctions cannot be sustained with the Internet. The Internet could, nevertheless, act as an equalizer of freedom of speech.

Part I of this article gives a brief background on the development of the Internet $^{7}$ and the constitutional issues arising from its use. With the everincreasing number of Internet users, ${ }^{8}$ complex jurisdictional questions for constitutional actions must be addressed.

Despite similarities in their constitutional provisions, the United States and India have their own unique jurisprudence on freedom of speech. Consequently, they differ as to what is and what is not acceptable free speech. This article comparatively analyzes obscenity laws in the United States and India. Part II summarizes the respective obscenity standards in the United States and India while debating whether these tests can be applied to the Internet.

Political $^{9}$ and economic ${ }^{10}$ considerations forced the regulation of the Internet in diverse areas. While regulators in the United States mainly deal with obscenity, ${ }^{11}$ regulators in India initially focused their attention on

6. Conventional media includes press, radio, television, etc, i.e., means of communication excluding the Internet.

7. The discussion on the Internet's development excludes commentary on who invented it.

8. As of September 2000, estimated users worldwide jumped to 377.65 million, up from 201.05 million the previous year. See Nua, How Many Online?, available at http://www.nua.ie/surveys/how_many_online/world.html (last visited Jan. 28, 2002). By 2000, the United States alone had 148.03 million users. See id. at http://www.nua.ie/surveys/how_many_online/n_america.html (last visited Jan. 28, 2002). The number of Internet users in India increased to 4.5 million in March 2000, up from 800,000 in May 1999. See id. at http://www.nua.ie/surveys/how_many_online/asia.html (last visited Jan. 28, 2002).

9. The public outcry over Internet porn is cited by the Congress as one of the main reasons for enacting the Communications Decency Act [hereinafter CDA]. See Robert Cannon, The Legislative History of Senator Exon's Communications Decency Act: Regulating Barbarians on the Information Superhighway, available at http://www.law.indiana.edu/fclj/pubs/v49/nol/cannon.html (last visited Jan. 28, 2002). Introducing the CDA, Senator Exon declared, "Barbarian pornographers are at the gate and they are using the Internet to gain access to the youth of America." Id.

10. A study by a London-based telecom consultancy projected a $\$ 54$ million loss to Videsh Sanchar Nigam Limited [hereinafter VSNL] by the year 2001 due to Internet Telephony. See The Financial Express Thursday, August 21 1997, available at http://www.financialexpress.com/fe/daily/19970821/23355653.html (last visited March 19, 2002).

11. The CDA and the Child Online Protection Act [hereinafter COPA] deal primarily with pornography on the Internet. Numerous states have also focused on the issue of Internet obscenity. See http://www.aclu.org/issues/cyber/censor/stbills.html (last visited March 19, 2002). 
protecting state revenue. ${ }^{12}$ Only recently has India made a legislative effort to control obscenity on the Internet. ${ }^{13}$ Part III analyzes the different approaches of the United States and India and discusses their legislative efforts at controlling obscenity on the Internet.

This article concludes, revealing that conventional free speech jurisprudence, enunciated by the courts in the United States and India, cannot be sustained with the Internet. The Internet's sheer volume of information ${ }^{14}$ necessitates that regulation occur through technological tools, ${ }^{15}$ which are bound to have limitations. ${ }^{16}$ Applying conventional tests using these imperfect tools could have a dreadful effect on freedom of speech. It is therefore critical that the judiciaries of the leading democracies recognize the potential dangers and protect freedom of speech on the Internet. If liberal standards are adopted for the Internet, there could be a uniform international standard for the freedom of speech.

\section{PART I - THE INTERNET}

\section{A. History}

The Internet is an outgrowth from a 1969 U.S. military program called ARPANET $^{17}$. The next phase of development came in the 1970s when universities and research centers all over the United States were given access. ${ }^{18}$ In the mid-1980s, the National Science Foundation took control of ARPANET and expanded its use to civilian networks. ${ }^{19}$ In the last decade, the introduction

12. India has mainly targeted Internet Telephony and other software packages. See discussion Infra Part III C

13. See Information Technology Act, 2000 (2000) [hereinafter IT Act].

14. Internet traffic is reported to double every three months. See. A Framework for Global Electronic Commerce, available at http://www.ecommerce.gov/framewrk.htm (last visited March 19, 2002)

15. Internet filtering and blocking software, proxy servers, ratings, green spaces, etc. are some of the common technological tools now in use. See Filtering tools available at http://www.media-awareness.ca/eng/webaware/tipsheets/filtering.htm (last visited March 19, 2002)

16. The COPA commission in its final report dated October 20,2000 , recognizes that several of the child protective technologies could have an adverse impact on privacy, First Amendment values, and law enforcement. See Final Report of the COPA Commission Presented to Congress, October 20, 2000, available at http://www.copacommission.org/report/ (last visited March 19, 2002).)

17. ARPANET is a network system developed by the Advanced Research Project Agency, through the Department of Defense, contributed by elite scientists from the RAND Corporation, MIT, and other scientific laboratories. See History of ARPANET, available at http://www.dei.isep.ipp.pt/docs/arpa.html (last visited March 19, 2002)

18. See A Brief History of the Internet, available at http://www.isoc.org/internet/history/ brief.shtml (last visited March 19, 2002).

19. See Reno v. ACLU, 521 U.S. 844, 850 (1997) (quoting findings of fact of ACLU v. Reno, 929 F. Supp. 824 (E.D. Pa. 1996)). 
of the World Wide Web dramatically changed public access to the Internet. ${ }^{20}$ The Internet, as we know it today, has experienced extraordinary growth. ${ }^{21}$ Government or state-owned institutions no longer control the Internet; multinational corporations now mainly control it. ${ }^{22}$

India was a late entrant to the Internet revolution. In 1987, the first dialup e-mail network was set up. In 1995 commercial Internet access was finally introduced. ${ }^{23}$ Thereafter, India experienced a technological revolution. Over forty private and government Internet Service Providers [hereinafter ISP] have emerged with over four million users ${ }^{24}$ by March $2000 .^{25}$

The rapid growth of the Internet is bound to cause numerous constitutional implications. Freedom of speech, right to privacy, right to information, and property rights are some key issues that are presently being debated. Other issues will undoubtedly arise as the Internet continues to expand. ${ }^{26}$ This article focuses, however, on the issue of freedom of speech as it relates in particular to obscenity on the Internet in the United States and India.

\section{B. Jurisdiction over the Internet}

The Internet is multi-jurisdictional by nature. Traditional notions of jurisdiction ${ }^{27}$ would have to be modified to activities carried out over the

20. See CDA, supra note 18 .

21. See Reno, 521 U.S. at 850.

22. See Andrew L. Shapiro, Street Corners in Cyberspace, THE NATION, July 3, 1995, available at $\mathrm{http} / / \mathrm{www}$.corpwatch.org/trac/internet/whoowns/streetcorners.html. State control of the Internet in the United States has been transferred to the private sector. See id. The federal government gradually transferred control to companies such as IBM and MCI, as part of a larger plan to privatize the Internet. See id. Shapiro warns of the danger of having "corporate giants" in charge. See id.

23. See History of GIAS available at, http://www.vsnl.com/english/userguide/giashist.htm (last visited March 19, 2002)

24. See Nua, How Many Online?, available at http://www.nua.ie/surveys/how many_online/asia.html (last visited Jan. 28, 2002).

25. See MICHAEL CONNORS, THE RACE TO THE INTELLIGENT STATE: CHARTING THE GLOBAL INFORMATION ECONOMY INTO THE 21ST CENTURY (170 to 212,1996 ) Connors states, "India is . . . an example of a relatively new phenomenon, the 'info-tiger economy,' one which exists within the broader economy but depends relatively little upon it; it operates according to its own rules and transcends national borders with unprecedented ease." Id.

26. See Marc L. Caden \& Stephanie E. Lucas, Accidents on the Information Superhighway: On-Line Liability and Regulation, 2 RICH. J.L. \& TECH. 3 (1996), available at http://www.richmond.edu/jolt/v2i1/caden_lucas.html; See also, Laurence H. Tribe, The Constitution in Cyberspace, available at $\mathrm{http}: / / \mathrm{www} . \mathrm{sjgames.com} / \mathrm{SS} /$ tribe.html (last visited Jan. 28, 2002).

27. This section does not discuss the complex jurisdictional questions raised by the Internet. Traditional implies the present State-controlled jurisdiction of the Internet using conflict of law theories. A Report of the President's Working Group on Unlawful Conduct on the Internet, March 2000, chaired by the Attorney General, recommended the following:

"[A]ny regulation of unlawful conduct involving the use of the Internet should 
Internet, ${ }^{28}$ as normal constraints on location are inapplicable. The Internet allows persons from geographically distinct jurisdictions to transact with each other, where little or no sensitivity is given to the potential consequences of their actions in the jurisdiction within which they are operating. ${ }^{29}$ Consequently, a stronger jurisprudence on conflict of laws should be developed for the Internet.

Within the United States, each state has separate laws that govern the activities of its citizens. As a result, considerable jurisprudence has emerged regarding conflict of laws in the United States. Where Internet-based disputes involve citizens of two separate jurisdictions, U.S. courts use conflict of law rules to determine what law should govern. That being the case, only a few decisions on Internet-related disputes have actually discussed the law relating to jurisdiction on the Internet. ${ }^{30}$ Normally, in the United States, two general

be analyzed through a policy framework that ensures that online conduct is treated in a manner consistent with the way offline conduct is treated, in a technology-neutral manner, and in a manner that takes account of other important societal interests, such as privacy and protection of civil liberties;"

The Electronic Frontier: The Challenge of Unlawful Conduct Involving the Use of the Internet available at http://www.usdoj.gov/criminal/cybercrime/unlawful.htm (last visited March 19, 2002) In India, Internet-related disputes fall under the jurisdiction of the newly created Central Tribunal for Adjudication of Cyber Disputes. See Ministry of Information Technology New Delhi, G.S.R. 791(E) Cyber Regulations Appellate Tribunal (Procedure) Rules, 2000, available at http://www.mit.gov.in/rules/main/htm (Oct. 17, 2000).

28. Speaking on the matter of jurisdiction as it applies to the Internet, one author writes, '[T]here exists in international law a type of territory [called] 'international space.' Currently there are three such international spaces: Antartica, outer space, and the high seas. For jurisdictional analysis, cyberspace should be treated as a fourth international space." Darrel Menthe, Jurisdiction in Cyberspace: A Theory of International Spaces, 4 MICH. TELECOMM. TECH. L. REV. 69 (1998), available at http://www.mttlr.org/volfour/menthe_art.html (last visited March 19, 2002). Others argue that the Internet should be regulated through the development of a parallel system of jurisprudence that is uniform for the entire realm of cyberspace. See David R. Johnson \& David G. Post, Law and Borders - The Rise of Law in Cyberspace, 48 STAN. L. REV. 1367 (1996), available at http://www.cli.org/X0025_LBFIN.html (last visited March 19, 2002) They state that conventional methods of ascertaining jurisdiction have no place in cyberspace, neither from the point of view of enforcement of rules and regulations nor from the traditional understanding of the need for distinct territorially separate jurisdictional demarcations. See id. Another states that regulation in cyberspace "is a function of the constraints of law, of norms, of the market, and of . . "code." Lawrence Lessig, Commentary, The Law of the Horse: What Cyberlaw Might Teach, 113 HARV. L. REV. 501 (1999). Finally, some others make a convincing argument that we should rely on traditional bodies of law, "[o]r at least start with those bodies of law and make adjustments and modifications to reflect the [Internet]." Andrew L. Shapiro, Symposium, Constitutional Issues Involving Use of the Internet: The Disappearance of Cyberspace and the Rise of Code, 8 SETON HALL CONST. L.J. 703 (1998); See also, Henry H. Perritt, Jr., Symposium, Will the Judgment-Proof Own Cyberspace?, 32 INT'L LAW. 1121 (1998).

29. See Rahul Matthan, Information Technology Law, available at http://www.naavi.com/cyberlaws/cyberlawsfr.htm.

30. See Thomas P. Vartanian, The Confluence of International, Federal, and State Jurisdiction over E-Commerce (Part II), available at http://www.gcwf.com/articles/journal/ jil_dec98_2.html\#27 (last visited March 19, 2002). 
principles govern a court's assertion of personal jurisdiction over a foreign party: state long-arm statutes and the Due Process Clause of the Constitution. ${ }^{31}$

India's jurisprudence on jurisdictional aspects of the Internet is virtually non-existent. Due to the strong unitary model of government followed in India, interstate disputes never rise to the level of private international law. As a result, there has been little development of conflict of law rules in India. India's courts have had few opportunities to actually assume jurisdiction over foreign subjects. However, when these opportunities occur, India's courts follow universal conflict of law theories. ${ }^{32}$ Now with recent passing of the Information Technology Act 2000 [hereinafter IT Act], India finally has a long-arm statute to assert its jurisdiction in court. ${ }^{33}$

Jurisdiction with respect to freedom of speech concerns like who can claim the right and file a complaint differs between the United States and India. In the United States, freedom of speech is guaranteed to citizens, as well as foreigners; however, in India, freedom of speech is only offered to its citizens. $^{34}$ This distinction further complicates the already complex jurisdictional issues associated with the Internet.

\section{PART II - OBSCENITY}

\section{A. Constitutional Borrowing}

The United States and India have similar free speech provisions in their Constitutions. The First Amendment to the U.S. Constitution provides, "Congress shall make no law... abridging the freedom of speech." 35 Similarly. Article 19(1) of India's Constitution provides, "All citizens shall have the right - (a) to freedom of speech and expression." ${ }^{36}$ The similarity draws from the framers of India's Constitution borrowing from their U.S. counterparts. ${ }^{37}$ Even today, the Supreme Court of India refers to U.S. decisions concerning the First

31. See Matthan, supra note 29.

32. See id.

33. See INFORMATION TECHNOLOGY ACT, 2000 (2000). Section 75 provides the following:

"(1) Subject to the provisions of sub-section (2), the provisions of this Act shall apply also to any offence or contravention committed outside India by any person irrespective of his nationality. (2) For the purposes of sub-section (1), this Act shall apply to an offence or contravention committed outside India by any person if the act or conduct constituting the offence or contravention involves a computer, computer system or computer network located in India." Id. $\$ 75$.

34. See Hans Muller v Supdt. (1955) 1 S.C.R. 1285, 1298.

35. U.S. CONST. amend. I.

36. INDIA CONST. art. XIX.

37. See I H.M. SEERVAI, CONSTITUTIONAL LAW OF INDIA 489 (3d edition 1983). 
Amendment. ${ }^{38}$ Despite the similarities, however, the United States and India have developed distinct standards for freedom of expression.

\section{B. United States}

The right of free speech is not absolute in the United States. ${ }^{39}$ The government may restrict speech in one of two ways. ${ }^{40}$ First, it may limit speech based on its content. Courts, however, subject all content-based regulations of speech to a strict scrutiny analysis, requiring that the regulation serve a compelling state interest through narrowly tailored means. ${ }^{41}$ The second way the government may abridge speech is by enacting statutes that seek to regulate not the content of speech, but rather some effect of it. If a statute regulates speech in the streets, parks, or other public forum, it must serve a significant governmental interest through narrowly tailored means. ${ }^{42}$

Obscenity is excluded from First Amendment protection. This stems from the fact that the framers of the First Amendment did not intend for all speech to be protected. ${ }^{43}$ The Supreme Court recognized that certain types of speech, such as obscenity, are harmful to society and are therefore not protected by the First Amendment. ${ }^{44}$ Even so, the Court continues to apply a strict scrutiny test to statutes abridging so-called "unprotected" speech. ${ }^{45}$

The Supreme Court first addressed the issue of First Amendment protection for obscenity in Roth v. United States. ${ }^{46}$ In Roth, the Court upheld the convictions of two defendants for violating California and federal obscenity statutes. ${ }^{47}$ Roth was convicted under the federal obscenity statute for mailing obscene advertisements and books. ${ }^{48}$ The majority opinion concluded

38. See Express Newspapers (Private) Ltd. v. Union of India (1959) 1 S.C.R. 12. In that case, Justice Bhagwati stated, "[that] the fundamental right to the freedom of speech and expression enshrined in...our constitution is based on (the provisions in) Amendment $I$ of the Constitution of the United States... and it would be therefore legitimate and proper to refer to those decisions of the Supreme Court of the United States of America in order to appreciate the true nature, scope and extent of this right in spite of the warning administered by this court against use of American and other cases." Id.

39. See Breard v. Alexandria, 341 U.S. 622, 642 (1951) (holding the constitutional guarantee of free speech is not absolute).

40. See Laurence Tribe, American Constitutional Law, 580. (Foundation Press Inc., 1978)

41. See Widmar v. Vincent, 454 U.S. 263, 270 (1981).

42. See Heffron v. International Society for Krishna Consciousness, Inc., 452 U.S. 640, 647 (1981) (holding "[t]he First Amendment does not guarantee the right to communicate one's views at all times and places or in any manner that may be desired.").

43. See WILLIAM BURNHAM, INTRODUCTION TO THE LAW AND LEGAL SYSTEM OF THE UNITED STATES 346 (2d ed. 1999).

44. See Miller v. California, 413 U.S. 15, 23 (1975).

45. See R.A.V. v. City of St. Paul, 505 U.S. 377, 383 (1992).

46. See Roth v. U.S., 354 U.S. 476 (1957).

47. See id. at 493-94.

48. See id. at 479-94. 
that obscene speech was not afforded protection by the First Amendment. ${ }^{49}$ The Court emphasized that the First Amendment protects any speech that has even the smallest redeeming social value, unless it infringes upon other more important freedoms. ${ }^{50}$ The Court defined obscene material as that which "deals with sex in a manner appealing to prurient interest." ${ }^{. " 1}$ The majority enunciated the following standard for determining whether material is obscene: "whether, to the average person, applying contemporary community standards, the dominant theme of the material, taken as a whole, appeals to prurient interest." 52 The Court concluded that obscenity is widely regarded as lacking any social importance and thus is not entitled to First Amendment protection. ${ }^{53}$

In 1973, the Supreme Court revisited the issue of obscenity. In Miller v. California ${ }^{54}$ the Court reviewed the defendant's conviction for using the mail to send unsolicited brochures depicting obscene matter in violation of California's obscenity statute. ${ }^{55}$ The majority announced a new three-part test for defining obscenity. ${ }^{56}$ The first part asks "whether "the average person, applying contemporary community standards' would find that the work, taken as a whole, appeals to the prurient interest." the work depicts or describes, in a patently offensive way, sexual conduct specifically defined by the applicable state law." ${ }^{\text {"58 }}$ Finally, the third part asks "whether the work, taken as a whole, lacks serious literary, artistic, political, or scientific value." 59 The Court determined that "contemporary community standards" should be used to determine obscenity and are "not "national standards," "which the Roth Court never intended to be used and which would prove unreasonable anyway. ${ }^{60}$ It stated, "It is neither realistic nor constitutionally sound to read the First Amendment as requiring that the people of Maine or Mississippi accept public depiction of conduct found tolerable in Las Vegas, or New York City." ${ }^{, 61}$ Nevertheless, the vagueness of this test has compounded the difficulty of defining what is obscene. ${ }^{62}$ This has caused a shift in states' policies dealing with obscenity, where instead of

49. See id. at $481-85$.

50. See id. at $484-85$.

51. Id. at 487.

52. Id. at $488-89$.

53. See id. at 485 .

54. See Miller v. California, 413 U.S. 15 (1973).

55. See id. at 15-18.

56. See id. at 23-25.

57. Id. at 24. The Miller Court defined prurient interest as "a shameful or morbid interest in nudity, sex, or excretion, which goes substantially beyond customary limits of candor in description or representation of such matters and is matter which is utterly without redeeming social importance." Id. at 18.

58. Id. at 24.

59. Id.

60. Id. at 37.

61. Id. at 32 .

62. See BURNHAM, supra note 43 , at 348. 
closing "adult" establishments under anti-obscenity laws, cities are concentrating efforts on regulating them through licensing and zoning. ${ }^{63}$

Currently the problem appears to be how to apply the "contemporary community standards" portion of the Miller test to the Internet. The Supreme Court faced similar challenges in the past when previous new media started to transmit indecent or otherwise impermissible material. ${ }^{64}$ Ever changing technology forced the Court to consider not only the content of the speech, but also the means used to convey it. ${ }^{65}$ In applying obscenity laws to media, courts tend to treat each one uniquely, including television, radio, books, newspapers, etc. ${ }^{66}$ Because the various media approach and reach audiences differently, determining the constitutionality of applying obscenity laws has been anything but uniform.

Aside from its vagueness, applying the Miller test to the Internet poses many other problems. ${ }^{67}$ First, it requires judges and juries to determine what the "community standards" are and to engage in literary criticism. Their nonexpertise, as well as the quantum of information that must be scrutinized, could overwhelm most judges and juries. Second, the reference to "contemporary community standards" necessarily means local standards. The Internet's very premise though is universal access, universal content, and a universal audience. This makes applying that part of the Miller test to the Internet almost impracticable, ${ }^{68}$ as attempting localized regulation of the Internet would only exacerbate the already confusing state of free speech regulation on the Internet. ${ }^{69}$

63. See id.

64. See, e.g., Sable Communications of California, Inc. v. FCC, 492 U.S. 115 (1989).

65. See id.

66. See JEROME A. BARRON \& C.THOMAS DIENES, HANDBOOK OF FREE SPEECH AND FREE PRESS $\$ 4.9$ and $\$ 10$ (1979).

67. See BURNHAM, supra note 43 , at 347

68. The application of contemporary community standards could never be met, for instance, when a corporation (developing filters and ratings) with office locations throughout the country has to evaluate whether or not certain Internet sites should be blocked. See Eileen Candia, Comment, The Information Super Highway-Caution-Road Blocks Ahead: Is the Use of Filtering Technology to Prevent Access to "Harmful" Sites Constitutional?, 9 TEMP. POL. \& CIV. RTS. L. REV. 85, 96 (1999).

69. First, with respect to how to regulate the Internet, there are different forms that Internet regulation can take. The alternative approaches to content regulation are:

1. Parental Supervision or regulating through parental control; See ACLU, Fahrenheit 451.2: Is Cyberspace Burning? How Rating and Blocking Proposals May Torch Free Speech on the Internet, available at http://www.aclu.org/issues/cyber/burning.html (last visited Feb. 1, 2002).

2. Publication Restriction or restricting the distribution of certain speech, i.e., child pornography; See id. (The CDA and COPA, discussed in Part III of this article, were attempts at content regulation through this type of approach.)

3. Filtering or using technology to block the display of certain content. See ACLU v. Reno, 929 F. Supp. 824 (E.D. Pa. 1996); See also, Thomas B. Nachbar, Article, Paradox and Structure: Relying on Government Regulation to Preserve the Internet's Unregulated Character, 85 MINN. L. REV. 215 (2000). Content 


\section{India}

Freedom of speech, though guaranteed, is not absolute in India. ${ }^{70}$ Unlike the U.S. Constitution, the text of India's Constitution clearly sets out restrictions on free speech. ${ }^{71}$ Laws that adhere to sub-clause (2) of Article 19 are expressly permitted by India's Constitution, as they are presumed to be constitutionally valid. ${ }^{72}$ The freedom of speech guarantee under Article 19(1)(a) can be subject to reasonable state restriction in the interest of decency or morality. ${ }^{73}$ The legislature's judgment, however, is subject to judicial review. ${ }^{74}$ India's courts apply the test of obscenity ${ }^{75}$ laid down by Chief Justice Cocburn in the Hicklin's case. ${ }^{76}$ Obscenity in India is defined as "offensive to modesty or decency; lewd, filthy and repulsive." Applying the Hicklin's test in Ranjit, the Supreme Court of India upheld a conviction under

filtering can be classified into four categories as follows:

a. Blacklisting or blocking access to those sites that are blacklisted; See Nachbar, supra.

b. Whitelisting or blocking access to all sites except those that are whitelisted; See id.

c. Content Examination Software or software that blocks certain words and phrases; See id.

d. Rating Based Filtering or applying ratings to content where the software excludes content if it assigned a particular rating, i.e., through the Internet Content Rating Association. See id.

With respect to who should regulate content on the Internet, legislation in both the United States and India places the burden on the content provider to evaluate their own content. See discussion infra Part III B \& C Third-party evaluation, i.e., rating agencies (government and non-government) may also take on the responsibility of regulating content on the Internet. The debate between filtering and publication restrictions and the one between private and governmental content regulation is beyond the scope of this article. For a detailed discussion, see Laurence Lessig, Symposium, Law and the Internet: Privacy, Jurisdiction, and the Regulation of Free Expression: What Things Regulate Speech: CDA 2.0 vs. Filtering, 38 JURIMETRICS J. 629 (1998); See also, Nachbar, supra.

70. See INDIA CONST. art. XXXII. This article guarantees a "right to Constitutional Remedies." Id. Furthermore, clause (4) provides, "The right guaranteed by this article shall not be suspended except as otherwise provided for by this Constitution." Id. cl. 4.

71. See id. art. XIX. Clause (2) provides the following:

Nothing in sub-clause (a) of clause (1) shall affect the operation of any existing law, or prevent the State from making any law, in so far as such law imposes reasonable restrictions on the exercise of the right conferred by the said subclause in the interests of the sovereignty and integrity of India, the security of the State, friendly relations with foreign States, public order, decency or morality, or in relation to contempt of court, defamation or incitement to an offence.

See id. cl. 2.

72. See INDIA CONST. art. XIX, cl. 2.

73. See id. cl. 2.

74. See SEERVAI, supra note 37 , at 490

75. See SEERVAI, supra note 37, at 530.

76. (1863) 3 QB 360, 371

77. Ranjit v. State of Maharashtra, 1965 A.I.R. (S.C.) $881,885$. 
the Indian Penal Code ${ }^{78}$ for being in possession, for the purpose of sale, a copy of D.H. Lawrence's Lady Chatterley's Lover. ${ }^{79}$ The Court held that an immodest representation may not be reasonably restricted in the interest of "decency and morality" if it leads to the propagation of ideas or information of public interest. ${ }^{80}$ It stated that the test of obscenity is whether the publication, read as a whole, has a tendency to deprave and corrupt those whose minds are open to such immoral influences, and therefore each work must be examined by itself. ${ }^{81}$ With respect to art and obscenity, the Court held that "the art must be so preponderating as to throw obscenity into a shadow or the obscenity so trivial and insignificant that it can have no effect and may be overlooked." emphasizing community mores, is that obscenity without a preponderating social purpose or profit cannot have the constitutional protection of free speech. ${ }^{83}$

India now faces the challenge to apply the Supreme Court's interpretation of the "reasonable restriction" test to the Internet. As previously mentioned, the Court emphasized that each work must be individually examined, applying community mores. ${ }^{84}$ The Internet, by its sheer volume, however, defies the application of this test.

Like the First Amendment to the U.S. Constitution, India's Constitution creates an absolute prohibition against limiting free speech without any exceptions. Exceptions, however, have evolved by judicial decisions, although their scope is limited. ${ }^{85}$ The fact that speech is presumptively constitutional in India, however, underscores the difficulty of reading into the "reasonable restriction" test, the limiting tests enunciated by the U.S. Supreme Court. ${ }^{86}$

Both U.S. and India's courts recognize the differences in the respective freedom of expression provisions. ${ }^{87}$ For example, Justice Douglas held that pre-censorship of cinema films is constitutionally void, stating that "if we had a provision in our Constitution for "reasonable" regulation of the press such as India has included in hers there would be room for argument that censorship in the interest of morality would be permissible." 88

78. Section 292 of the Indian Penal code was held constitutional, as it did not go beyond "obscenity," which fell directly within the words "public decency or morality" mentioned in Article 19(2). See id. at 887

79. See id. at 887. id. at 887

80. The court cited the example of books on Medical science as being informative. See

81. See id. at 888.

82. See id.

83. See id. at 889.

84. See id.

85. See SEERVAI, supra note 37 , at 490.

86. See id.

87. See Kingsley International Pictures Corp. v. Regents of the University of New York, 360 U.S. 684, 698 (1959).

88. Id. 
India's courts in the past have turned to U.S. First Amendment cases for guidance. ${ }^{89}$ Nevertheless, the United States and India have adopted different tests to judge obscenity. The real difference, however, appears to be a question of degree, ${ }^{90}$ which varies according to the moral standard of the community in question. ${ }^{91}$ It would be fair to state though that the "reasonable restriction" test, as interpreted by India's Supreme Court, imposes greater restrictions on freedom of speech than the tests followed in the United States. ${ }^{92}$

\section{PART III - OBSCENITY ON THE INTERNET}

\section{A. Free Speech Jurisprudence and the Internet}

The United States has a complex First Amendment jurisprudence that varies the protection offered free speech according to form. ${ }^{93}$ Similarly, India developed its own free speech jurisprudence that applies a "reasonable restrictions" test based on eight listed restrictions. ${ }^{94}$ These respective restrictions as applied to the Internet raise some important freedom of speech issues in both the United States and India. ${ }^{95}$

\section{B. United States}

First Amendment jurisprudence varies free speech rights according to the technological medium that is used for expression. ${ }^{96}$ Historically, print media (newspapers and magazines) receives the greatest consideration and leniency by U.S. courts while broadcast media (television and radio) the least. ${ }^{97}$ The difficulties in applying traditional free speech concepts to such a widely different medium has not discouraged the Congress in its efforts to regulate the Internet. Under the auspices of "[its] compelling interest in protecting children

89. See Ranjit v. State of Maharashtra, 1965 A.I.R. (S.C.) 881, 889-90. The U.S. tests were considered before finally arriving at the "reasonable restriction" test used in India. See id.

90. See id. at 885 . Justice Hidayatullah stated, "Condemnation of obscenity depends as much upon the mores of the people as upon the individual. It is always a question of degree or as the lawyers are accustomed to say, of where the line is to be drawn." Id.

91. See id. at 889. Justice Hidayatullah used "judged by our national standards" to convey different standards for different countries. See id.

92. See Kingsley, 360 U.S. at 684; See Ranjit, 1965 A.I.R. (S.C.) at 881; See also, DURGA DAS BASU, SHORTER CONSTITUTION OF INDIA (1988).

93. These include the marketplace, self-fulfillment, social outlet, and political theories of free speech. (CLARIFY SENTENCE; NEED SOURCE, CITE)

94. See INDIA CONST art. XIX. Clause (2)

95. For a detailed discussion on U.S. Congressional and State actions to regulate the Internet, see Caden \& Lucas, supra note 26.

96. Southeastern Promotions, Ltd v. Conrad, 420 U.S. 546, 557

97. See Turner Broadcasting System, Inc. v. FCC, 512 U.S. 622, 636-40 (1994). 
from exposure to sexually explicit material," ${ }^{, 98}$ Congress enacted legislation to regulate and protect children using the Internet. ${ }^{99}$

In response to public concern over minors' seemingly unhindered access to indecent material on the Internet, Congress passed the Telecommunications Act of 1996 [hereinafter Act]. ${ }^{100}$ Title V of the Act, commonly referred to as the Communications Decency Act [hereinafter CDA], criminalized indecent speech on the Internet aimed at minors. ${ }^{101}$ It prohibited and punished intentional transmission of obscene or indecent communication to recipients under the age of eighteen (the "indecent transmission" provision), ${ }^{102}$ as well as intentional sending or displaying of patently offensive messages in any manner to the same (the "patently offensive" display provision). ${ }^{103}$ The Act immediately sparked controversy. On the very day President Clinton signed the bill into law, a group of plaintiffs, led by the American Civil Liberties Union [hereinafter ACLU], filed suit against the Attorney General and the Department of Justice challenging the constitutionality of the CDA. ${ }^{104}$ Following the district court's grant of a temporary restraining order against its enforcement, several additional plaintiffs filed suits. The cases were consolidated and a three-judge panel convened, which unanimously granted a preliminary injunction against enforcing the CDA's provisions. ${ }^{105}$ The

98. See Reno v. ACLU, 521 U.S. 844, 875 (1997). The Supreme Court acknowledged that it "[has] repeatedly recognized the governmental interest in protecting children from harmful material."

99. See, e.g., Child Online Protection Act, H.R. 3783, 105th Cong. (1998); Internet Indecency Act, S. 1482, 105th Cong. (1997); Safe Schools Internet Act, H.R. 3177, 105th Cong. (1998); E-Rate Policy and Child Protection Act, H.R. 3442, 105th Cong. (1998); Internet Freedom and Child Protection Act, H.R. 774, 105th Cong. (1997); Communications Privacy and Consumer Empowerment Act, H.R. 1964, 105th Cong. (1997); Family-Friendly Internet Access Act, H.R. 1180, 105th Cong. (1997).

100. See Telecommunications Act of $1996 \S 502,47$ U.S.C.A. $\$ 223$ (West 2001).

101. See id.

102. See id. Section $(a)(1)(B)$ provides,

"Whoever ... by means of a telecommunications device knowingly ... initiates the transmission of any comment, request, suggestion, proposal, image, or other communication which is obscene or indecent, knowing that the recipient . . . is under 18 years of age, regardless of whether the maker of such communication placed the call or initiated the communication ... shall be fined . . . or imprisoned not more than two years, or both." Id. $\$ 223(\mathrm{a})(1)(\mathrm{B})$.

103. See id. \& 223(d)(1). Section (d)(1) provides, "Whoever in interstate or foreign communications knowingly uses an interactive computer service to send to a specific person or persons under 18 years of age, or uses any interactive computer service to display in a manner available to a person under 18 years of age, any comment, request, suggestion, proposal, image, or other communication that ... depicts or describes ... patently offensive ... sexual or excretory activities or organs, regardless of whether the user of such service placed the call or initiated the communication ... shall be fined ... or imprisoned not more than two years, or both." Id.

104. See Cyberspace must be free, available at http://www.aclu.org/issues/cyber/ hmcl.html. (last visited March 19, 2002).

105. See ACLU v. Reno, 929 F. Supp. 824, 883 (E.D. Pa. 1996). 
Government appealed the district court's decision, as the Supreme Court granted expedited jurisdiction to review the constitutionality of the CDA. ${ }^{106}$ On June 26, 1997, the U.S. Supreme Court decided its first ever case involving the Internet, Reno v. ACLU. ${ }^{107}$ The Court ruled that the CDA violates the First Amendment's guarantee of freedom of speech. ${ }^{108}$

The majority opinion recognized that " $[t]$ he Internet is 'a unique and wholly new medium of worldwide human communication." 109 It found that "“cyberspace' [is] located in no particular geographical location but available to anyone, anywhere in the world, with access to the Internet." 10 It held that the CDA had vagueness problems, which undermined its purpose, ${ }^{111}$ stating that it "suppresses a large amount of speech that adults have a constitutional right to receive and to address to one another." 12

Reno's dissenting opinion agreed with the majority that the CDA placed too much of a burden on adult speech. ${ }^{113}$ However, the dissent viewed the CDA as a form of "cyberzoning" akin to a time, place, and manner restriction, and not as a content-discriminatory ban. ${ }^{114}$ It concluded that the law was constitutional in part "as applied to a conversation involving only an adult and one or more minors, e.g., when an adult speaker sends an e-mail knowing the addressee is a minor." 115

After the Reno decision, Congress attempted to remedy the constitutional defects of the CDA with the Child Online Protection Act [hereinafter COPA]. ${ }^{116}$ Before COPA went into effect, plaintiffs similar to the Reno

106. See Reno v. ACLU, 521 U.S. 844, 883 (1997). The Court based its expedited jurisdiction on 47 U.S.C.A. $\$ 561$ (1997). See id.

107. See id. at 882-85.

108. See id.

109. See id. at 850.

110. Id. at 851 .

111. See id. at 870-79. The CDA was aimed at "protecting minors from potentially harmful [or indecent] materials" available on the Internet. Id. at 871.

112. Id. at 874 .

113. See id. at 888 .

114. See id. at 893.

115. Id. at 892. For a critical analysis of this case, see Mark S. Kende, Article, The Supreme Court's Approach to the First Amendment in Cyberspace: Free Speech as Technology's Hand-Maiden, 14 CONST. COMMENTARY 465 (1997).

116. See Child Online Protection Act, 47 U.S.C.A $\$ 231$ (West 2001). Section (a)(1) provides,

"Whoever, in interstate or foreign commerce, by means of the World Wide Web, knowingly makes any communication for commercial purposes that includes any material that is harmful to minors, without restricting access to such material by minors pursuant to subsection (c), shall be fined not more than $\$ 50,000$, imprisoned not more than 6 months, or both." $1 d$. \$231(a)(1).

Section (e)(6) defines harmful material to minors as,

"any communication, picture, image, graphic image file, article, recording, writing, or other matter of any kind that the average person ... would find ... is designed to appeal ... to the prurient interest; depicts, describes, or represents, in a manner ... offensive with respect to minors, an actual or simulated sexual 
plaintiffs challenged the constitutionality of the statute, seeking injunctive relief. ${ }^{117}$ The plaintiffs attacked COPA for placing an unconstitutional burden on adults for protected speech, for violating First Amendment rights of minors, and for being unconstitutionally vague in violation of the First and Fifth Amendments. ${ }^{118}$ The defendants argued that the statute's requirements did not burden adults' access to constitutionally protected speech, and that the affirmative defenses represented technologically and economically feasible methods to restrict minors' access to targeted websites. ${ }^{119}$ After hearing these arguments, the district court granted a preliminary injunction against the government. ${ }^{120}$

The government challenged the preliminary injunction to the United States Court of Appeals for the Third Circuit, which upheld the preliminary injunction. ${ }^{121}$ The Third Circuit held that COPA required every web publisher to abide by the most restrictive and conservative state community standards in order to avoid criminal liability, and that this constituted an impermissible burden on constitutionally protected speech. ${ }^{122}$ The Court noted, however, "[it] is undisputed that the government has a compelling interest in protecting children from material that is harmful to them, even if it is not obscene by adult standards." 123 Nevertheless, it affirmed the sentiments of the District Court, stating, "'sometimes we must make decisions which we do not like. We make them because they are right, right in the sense that the law and the Constitution, as we see them, compel the result." 124

By introducing such new standards as "patently offensive" and "harmful to minors," Congress continues its effort to regulate obscenity on the Internet. The CDA digressed some from the Miller test, yet still adopted the language "patently offensive as measured by contemporary community standards." 125 Even so, the U.S. Supreme Court struck it down as unconstitutional. ${ }^{126}$ Congress then digressed further, adopting the retooled community standard enunciated in COPA. That standard has since been abandoned, however,

act .. or contact ... or a lewd exhibition of the genitals or female breast; and

[that]. . . lacks ... literary, artistic, political, or scientific value for minors." Id.

$\S 231(\mathrm{e})(6)$.

Section (e)(7) defines minor as, "any person under 17 years of age." Id. \& (e)(7).

117. See ACLU v. Reno, 31 F. Supp.2d 473, 477 (E.D. Pa. 1999).

118. See id, at 478-79.

119. See id. at 479.

120. See id. at 492-99. For a detailed discussion on COPA, see Abbigale E. Bricker, Note, You Can't Always Get What You Want: Government's Good Intentions v. The First Amendment's Prescribed Freedoms in Protecting Children From Sexually-Explicit Material on the Internet, 6 RICH. J.L. \& TECH. 17 (1999-2000), available at http://www.richmond.edu/ JOLT/v6i3/note5.html (last visited Feb.2, 2002).

121. See ACLU v. Reno, 217 F.3d 162, 181 (3d Cir. 2000).

122. See id. at 177.

123. Id. at 173.

124. Id. at 180 (quoting ACLU, $31 \mathrm{~F}$. Supp.2d at 498).

125. See Reno v. ACLU, 521 U.S. 844 (1997).

126. See id. 
leaving U.S. courts to scrutinize Congress' newest standard, that of "harmful to minors."

U.S. courts are also developing a new regulatory standard for Internet speech, one which is technology driven. ${ }^{127}$ As "a new medium of mass communication," the Internet compels courts to consider its special qualities in determining the constitutionality of such regulation. ${ }^{128}$ Dealing with the CDA and COPA, U.S. courts extensively discussed existing technology and their effectiveness in regulating the Internet. ${ }^{129}$ The Supreme Court, for instance, supported its holding on the CDA by adopting the district court's finding that "existing technology did not include any effective method for a sender to prevent minors from obtaining access to its communications on the Internet without also denying access to adults." ${ }^{130}$ This underscores the difficult technological aspect of regulating speech on the Internet and the significance it plays in the approaches continued to be taken by U.S. courts and legislative bodies.

\section{India}

Unlike the U.S. experience, which represents the difficulty in legislating free speech on the Internet, India's experience exhibits the contrary. ${ }^{131}$ Until recently, India's government simply regulated the Internet through its stateowned ${ }^{132}$ monopoly, Videsh Sanchar Nigam Limited [hereinafter VSNL]. ${ }^{133}$

127. See Candia, supra note 68 , at 100 . On March 25, 2002, the trial challenging Congress' third attempt at censoring the Internet (via the Children's Internet Protection Act, known as CIPA) got underway. See Blocking Programs on Trial, available at http://www.aclu.org/court/CIPA_Intro.html (last visited March 27, 2002). This legislation requires libraries that participate in certain federal programs to install "technology protection measures" on all of their Internet access terminals. See id.

128. See, e.g., ACLU v. Reno, 929 F. Supp. 824 (E.D. Pa. 1996). The Internet possesses certain qualities as a medium of communication. First, the Internet presents very low barriers to entry. See id. Second, these barriers to entry are identical for both active and passive users. See id. Third, as a result of these low barriers, astoundingly diverse content is available on the Internet. See id. Fourth and finally, the Internet provides significant access to all who wish to use it, and even creates a relative parity among users.

129. See, e.g., Reno, 521 U.S. at 844; See also, ACLU, 217 F.3d at 162.

130. Reno, 521 U.S. at 876.

131. (As evidenced by the IT Act's easy passage and lack judicial review thereafter.

132. After the public issue of 1999 , private investors held $45.6 \%$ of VSNL's equity. See VSNL: Corporate Profile, available at http://www.vsnl.net.in/english/corporate.html (last visited Feb. 2, 2002). In February 2002 the Cabinet Committee on Disinvestments (CCD) cleared the sale of $25 \%$ stake in VSNL to the Tata group. After the sale the Government's equity in VSNL stood diluted to $28 \%$ and the Tata group took over the management of VSNL. See Tata Group to take over VSNL available at http://www.tata.com/tata_sons/ media/20020212.htm (last visited March 19, 2002)

133. See VSNL: Corporate Profile, available at http://www.vsnl.net.in/english/ corporate.html (last visited March 19, 2002). VSNL was a government controlled corporation until February 2002, it controled all the international gateways of India. See id. All international communications, telephone calls, faxes, etc. had to be routed through the international gateways, which were under the control of VSNL. See id. VSNL was the only 
Such regulation was not prompted by the desire to protect children, but rather to protect state revenue. ${ }^{134}$

In 1997, a website distributing a software package ${ }^{135}$ was blocked by VSNL. ${ }^{136}$ The software permitted text customers to browse the net graphically. VSNL charged exorbitant rates for similar graphic service, standing to lose potentially substantial revenue because of this competition. ${ }^{137}$ The government justified the illegal blocking of the website on the grounds that the software distributed did not comply with the provisions for text accounts, thus threatening the quality of Internet services to all users. ${ }^{138}$ India's courts, however, never tested this illegal blocking of a website. ${ }^{139}$

Through 1997 and 1998, VSNL continued their strong-arm tactics, including blocking websites ${ }^{140}$ and threatening action against subscribers. ${ }^{141}$ Angered by these occurrences, Dr. Arun Mehta, a free speech activist, petitioned the Delhi High Court. ${ }^{142}$ Dr. Mehta argued that "[blocking websites] is wholly without basis in law and amounts to arbitrary and illegal censorship of the petitioner's Fundamental Right to freedom of speech, expression and information as well as an illegal denial of his right to freedom to practice

ISP in India. See id. The ISP business opened to competition in November 1998. See id. As of March 31, 2000, seventy private ISPs were operating, while 315 new, private ISPs received licenses. See id. Despite the growth of private providers, VSNL still controls around $70 \%$ of the ISP market.See id. VSNL's exclusive rights in international telephony will continue until April 1, 2002. See id.

134. See Financial Express, supra note 10

135. Xtend Technologies Private Limited developed the software called Shellshock. See VSNL Blocks Shellshock SW Usage, available at http://www.indiatoday.com/ctoday/111997/buzz3.html\#vsnl (last visited March 19, 2002)

136. See id. At the time, VSNL constituted the only ISP in India, using its monopoly status to install filters to stop direct access to websites.

137. See Silencing the Net: The Threat to Freedom of Expression OnLine, 8 HUMAN RIGHTS WATCH 2, May 10, 1996, at 1-2, available at http://www.epic.org/free_speech/ intl/hrw_report_5_96.html. (last visited March 19, 2002)

138. See Dr. Raj Mehta, Censorship and Intemet in India: Can We Keep Internet in India Free?, available at http://guide.vsnl.net.in/tcpip/columns/censorship/cc04.html (last visited Feb. 4, 2002)

139. See idThis illegal blocking was probably never tested by the courts because VSNL lifted the block on the website in just a few months. During the time of its illegal blocking of the website, VSNL worked out a way to break Shellshock. See id. It achieved this by further restricting the environment on its text accounts to the extent that Shellshock could not function. See id.

140. See Mehta v. VSNL, 1998 Indian Dec. W.P. 4732 (Delhi H.C.), available at http://members.tripod.com/ india_gii/telepet.html. VSNL's blocking activities continued, as evidenced by an email it sent to its subscribers on Jan. 5, 1998, stating, "As you are aware, the usage of Telephony on the Internet is not permitted as per the terms and conditions of your Internet subscription and the Indian rules and regulations." Id.

141. See id. VSNL also made threats, as evidenced by the following statement included in a Jan. 5, 1998 email to its subscribers, stating, "You are advised not to use the Internet connection for Telephony or Fax applications. VSNL would be monitoring the use of Internet and those subscribers who are found to be violating the conditions of subscription, would be permanently debarred from using Internet services." Id.

142. See id. 
his chosen profession." 443 VSNL responded, brushing aside the constitutional challenge and arguing that a contractual provision did not permit subscribers to use the telephony service for interactive voice or fax message. ${ }^{144}$ The Court admitted Dr. Mehta's petition, which is now pending a final hearing. ${ }^{145}$

Entry of Private ISPs ${ }^{146}$ to some extent forced VSNL to change its ways, although it continued ${ }^{147}$ to control the international Internet gateways that every Indian ISP had to use. ${ }^{148}$ In June 1999, VSNL once again used its control of the gateways to block subscribers' access to the news site of Dawn, a leading newspaper in Pakistan. ${ }^{199}$ VSNL argued that the blocking was legal, under authority given by the Indian Telegraph Act. ${ }^{150}$ The blockade proved ineffective, however, as websites began posting information, instructing how to break it and others like it. ${ }^{151}$

As the number of private ISPs increased, contractual restrictions and executive orders were not an effective way for VSNL to control the Internet. While the arbitrary dictate of VSNL attracted some attention, ${ }^{152}$ India's government enacted the IT Act ${ }^{153}$ without much opposition. ${ }^{154}$

143. Id.

144. See id. VSNL relied on the standard account opening form signed by new subscribers, which stated that the account could not be used for telephony and fax services. See id. It argued, "It is denied that the no-provision of certain routes on the Internet amounts to a violation of the fundamental rights guaranteed under the Constitution." Id.

145. See Status of VSNL censorship of IP-telephoney sites, available at: http://members.tripod.com/ india_gii/statusof.htm (last visted March 19,2002). The matter was last heard on August 9, 2001 when VSNL pressed for dismissal of the matter on the grounds that the petition was now moot as the sites were no longer blocked. See id Justice Mukul Mudgal did not dismiss the petition and gave liberty to Petitioners to approach the court for an immediate hearing if VSNL blocked any more sites. See id In reply to this petition VSNL strenuously argued against Internet telephony. See id Ironically a year later VSNL announced plans to launch its own Internet telephony service. See VSNL ready to offer ATM-based Internet telephony, available at http://www.zdnetindia.com/news/national/stories/24419.html (last visited March 19, 2002)

146. Pursuant to domestic and international pressure, as well as the WIPO agreement, private ISPs were finally allowed by November 1998. See VSNL: Corporate Profile, supra note 132.

147. VSNL's monopoly on international gateways ended in July 1999 with the issuance of guidelines for private international Gateways, See India Permits Private Gateways, With Strings Attached, available at http://asia.internet.com/asia-news/article/0,,161_ 650621,00.html(last visted March 19,2002). The first four applications for private international gateways were cleared only in January 2002, See India to Have 4 Private International Gateways Soon, available at http://asia.internet.com/asia-news/article/0,161_653161,00.html (last visited March 19, 2002).

148. See Rediff On The Net, Who Ordered the Blockade in the First Place?, available at http://www.rediff.com/computer/1999/jul/05dawn.htm.(last visited March 19, 2002)

149. See id.

150. See id.

151. See Rediff On The Net, How to Break the Blockade, available at http://www.rediff.com/computer/1999/jul/05dawn.htm.

152. See Human Rights Watch, supra note 3.

153. See IT ACT, 2000 (2000).

154. See supra note 131 
The IT Act shares in creating an environment for electronic commerce. ${ }^{155}$ It serves as the fundamental mechanism for legalizing electronic transactions, ${ }^{156}$ but it also represents, however, an indirect attempt by India's government to impose restrictions on the freedom of speech and privacy on the Internet. ${ }^{157}$ As it reflects the prevailing political culture, the IT Act embodies the view that the Internet is something that can and must be regulated before it gets out of control.

Section $67^{158}$ of the IT Act is designed to deter publication and transmission of obscene information in electronic form. ${ }^{159}$ Just like the U.S. COPA equivalent, this section departs from the test enunciated by the U.S. Supreme Court. ${ }^{160}$ Under Section 67, "any material which is lascivious or appeals to the prurient interest or ... tend[s] to deprave and corrupt persons who are likely ... to read, see or hear the matter ... " is considered obscene. ${ }^{161}$ The section imposes dual punishment on offenders, including a fine and imprisonment up to a maximum term of ten years. ${ }^{162}$

Through the IT Act's passage, India's legislature ignored the "lewd, filthy and repulsive" and "preponderating social purpose" tests associated with earlier attempts at regulation. ${ }^{163}$ Section 67 retains only the "tendency to deprave and corrupt" test. ${ }^{164}$ It introduces two new standards, "lascivious" and "appealing to prurient interest," 165 similar to COPA's introduction of new standards in the United States. These new standards even bear resemblance to COPA's provisions. ${ }^{166}$ In addition, Section 67 appears to be as vague as COPA yet remains unchallenged, ${ }^{167}$ reflecting the emergence of a new

155. See IT ACT, 2000 (2000).

156. See id.

157. See id. $\$ \S 29,67$.

158. See id. $\$ 67$. This section, entitled "Publishing of information which is obscene in electronic form," provides, "Whoever publishes or transmits . . . in . . . electronic form, any material which is lascivious or appeals to ... prurient interest or if [it] ... tend[s] to deprave and corrupt persons ... shall be punished . . . with imprisonment ... and with fine ..."Id.

159. See id.

160. See Ranjit v. State of Maharashtra, 1965 A.I.R. (S.C.) 881. (CONFIRM THIS CITE)

161. IT ACT, $2000 \S 67$ (2000).

162. See id.

163. See id

164. See id

165. See id

166. The IT ACT, 2000 uses language similar to COPA with respect to the "prurient interest" provision.

167. An online search for petitions challenging IT ACT, $2000 \$ 67$ did not reveal any filings as of March 19,2002. One interesting petition is the one pending in Bombay High Court, Writ Petition 2611 of 2001. See Protecting Minors from Unsuitable Internet Material, available at $\mathrm{http}: / / \mathrm{www}$.bombaybar.com/cyberreport/cover.html (last visited March 24, 2002). A letter from Jayesh Thakkar and Sunil Thacker to the Chief Justice of the Bombay High Court complaining about the proliferation of pornographic sites on the Internet was treated as a suo motu Writ Petition. The Division Bench of the High Court, presided over by the Chief Justice, passed an order appointing a Committee to suggest and recommend ways, measures, and means to protect/shield minors from access to pornographic and obscene material on the Internet. See id. The Committee comprehensively rejected the proposal for site blocking as being 
regulatory standard for Internet speech in India.

Sections $29^{168}$ and $69^{169}$ of the IT Act give officers ${ }^{170}$ unrestricted access to computer systems, apparatus, and data, disregarding the established standard of privacy. ${ }^{171}$ Section $72,{ }^{172}$ however, imposes a penalty on an officer for breach of confidentiality or privacy. ${ }^{173}$ Even so, this is inadequate to police the potential abuse of the sweeping powers given to officers under the Act. ${ }^{174}$

As already discussed, India's courts have thus far been left out of the debate on the freedom of speech on the Internet. Consequently, India's regulators have had a seemingly free ride in their attempts to regulate the Internet. The apparent reasons for this could be summarized as follows: (1) The arbitrary blocking of websites (such as that of Shellshock and Dawn) lasted only temporarily and, therefore, eluded necessary testing by India's courts; (2) The blocking of Internet telephony sites did not constitute actionable harm for either the owners or their attempted users, as the majority non-Indian owners could not seek redress in India's courts, and standard VSNL user contracts explicitly prevented account users telephony and fax applications; (3) The IT Act's infancy necessarily means India's courts have not had an opportunity to scrutinize it; and (4) India's Civil liberties organizations are not well equipped to handle constitutional issues related to freedom of speech on the Internet.

technically and legally unsound. See id. The Committee's recommendations included requiring that minors be restricted to using machines in the common open space of Cyber Cafes and requiring that these machines be fitted with software filters providing for the maintenance of Internet Protocol address. See id. During the subsequent hearings, the Internet Users Association of India (IUAI) was permitted to intervene in the matter. See id. On February 13, 2002, the High Court passed an order stating that the report by the Special Committee be made available to the public online for download to enable comments and suggestions. See id. The matter stood over for further orders until April 13, 2002. See id.

168. See IT ACT, $2000 \S 29$ (2000). This section, entitled "Access to computers and data," provides, "the Controller or any person authorized by him shall, if he has reasonable cause to suspect that any contravention of the provisions of this Act ... has been committed, have access to any computer system ... for the purpose of searching ... any information or data contained in . . such computer system." Id. $\$ 29(1)$.

169. See id. $\$ 69$. This section, entitled "Directions of Controller to a subscriber to extend facilities to decrypt information," provides, "If the Controller is satisfied that it is necessary . .. to do in the interest of ... public order or for preventing incitement to the commission of any cognizable offence . . . direct any agency of the Government to intercept any information transmitted through any computer resource." Id. \$ 69(1).

170. The IT Act does not refer to "officer." See id. $\$ \S 29,69$. It is being used here as a general term for the Controller and those authorized by him under the Act.

171. See id.

172. See id. $\$ 72$. This section, entitled "Penalty for breach of confidentiality and privacy," provides, "Save as otherwise provided ... any person who ... has secured access to any electronic record ... or other material without the consent of the person concerned ... discloses such electronic record ... or other material to any other person shall be punished with imprisonment ... or with fine ... or with both." Id.

173. See id.

174. Despite numerous powers, the IT Act provides only two grounds for sanctioning erring officers. See id 
The most significant reason though for the apparent unchallenged acceptance of government restrictions on the Internet seems to be India's citizens' nonchalant attitude towards the operation of these restrictions. With conventional media, the means and degree of regulation are relevant, sensitive considerations. In the case of the Internet, however, regulations have passed almost unnoticed because of the historically high degree of freedom enjoyed with its use. The mentioned restrictions seem a bit hollow when compared to the widespread availability of the Internet. The reality is that the Internet allows its users to easily access information that in the past may have been unobtainable, or at the very least difficult to procure, without much thought about the transmission.

\section{CONCLUSION}

Differences in the right to free speech in the United States and India lie largely in the means used to protect this right and the degree of freedom enjoyed. In the United States, adopting a standard that adequately identifies obscene material has been anything but easy. Conventional media, as well as the Internet, have made this a difficult task, as each created problems for the three-part test for obscenity originally offered in Miller. India has struggled too, as the standard, "preponderating social purpose," laid down in Ranjit, has proven impractical when applied. The vagueness and uncertainty surrounding these attempted regulatory standards, coupled with the Internet's inherent defiant attitude toward regulation, caused them to infringe upon adults' rights, while trying to protect children's interests. ${ }^{175}$ Both legislatures, therefore, enacted new standards ${ }^{176}$ for regulating obscenity on the Internet. These new standards aim to maintain the distinctions that have evolved with conventional media, while attempting to regulate the Internet more precisely. Even if they could overcome their vagueness problems, it seems improbable that such provisions could be implemented. ${ }^{177}$ The Internet cannot relate to the current methods adopted by the United States and India that restrict freedom of speech. It can, however, temper the differences in these means, and in doing so, could act to equalize the means adopted to regulate freedom of speech.

As mentioned, the real difference in freedom of speech enjoyed in the United States and India is a question of degree. ${ }^{178}$ This difference in degree is attributable to the reasonable restrictions provision ${ }^{179}$ and the moral standard of the communities. ${ }^{180}$ India has progressed from an authoritarian system ${ }^{181}$ of control and is now attempting a legislative model of control, quite similar to

175. See Reno v. ACLU, 521 U.S. 844, 882-84 (1997).

176. These new standards include COPA and the IT Act.

177. See Candia, supra note 68 , at 104

178. See Ranjit v. State of Maharashtra, 1965 A.I.R. (S.C.) 881, 885.

179. See INDIA CONST. art. XIX.

180. See Ranjit, 1965 A.I.R. (S.C.) at 889.

181. In so far as the state-owned monopoly, VSNL, was arbitrarily regulating the Internet. 
that of the United States. In India, the degree of freedom enjoyed on the Internet has far exceeded any similar freedom enjoyed with conventional media. The Internet provides access to all who wish to use the medium, and has created a relative parity among all users. ${ }^{182}$ Moreover, the sheer volume of information made available by the Internet has substantially diluted the difference in the degree of freedom enjoyed in the United States and India.

The expanse and indefinable growth of the Internet ${ }^{183}$ suggests that technology will play a key role in any future attempt at its regulation. ${ }^{184}$ The difficulty lies in finding mechanisms that will selectively police content without infringing on the protected speech rights of its users. A group of hightech companies ${ }^{185}$ is currently joining forces to develop such a system to cope with indecent materials in Cyberspace. ${ }^{186}$ Its proposed effect on freedom of speech on the Internet can only be speculated at this time. ${ }^{187}$ Government lawmakers and judiciaries are also proceeding with newly adopted standards. ${ }^{188}$ It is imperative, however, that any and all attempts at regulating Internet speech be uniform globally to allow the Internet to retain its universal character. As the most participated form of mass speech out there, the Internet deserves the highest protection. ${ }^{189}$ We have the opportunity with this duty to do something more, develop a uniform international standard for the freedom of speech.

182. See ACLU v. Reno, 929 F. Supp. 824,877

183. See Framework supra note 14.

184. See Mainstream Loudoun v. Board of Trustees of the Loudoun County Library, 2 F. Supp.2d 783, 792 (E.D. Va. 1998).

185. This group consists of approximately two-dozen corporations, including Microsoft Corp., Apple Computer Co., AT\&T Corp., Time Warner, Inc., and Spyglass, Inc. See Caden \& Lucas, supra note 26. Led by the World Wide Web Consortium at the Massachusetts Institute of Technology, it intends to develop a selection or rating system entitled "Platform for Internet Content Selection" or "P.I.C.S.". See id.

186. See id.

187. See Shapiro, supra note 22.

188. See, e.g., ACLU v. Reno, 929 F. Supp. 824, 881

189. See generally Id. 